\title{
The potential use of anoxygenic phototrophic bacteria for treating latex rubber sheet wastewater
}

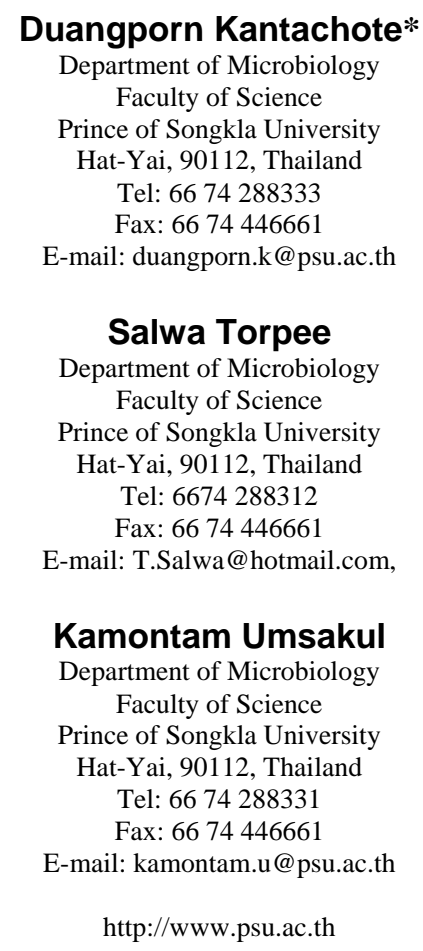

Financial support: This work was supported by the Faculty of Science, Prince of Songkla University, Thailand.

Keywords: biochemical oxygen demand(BOD), chemical oxygen demand(COD), purple non sulphur photosynthetic bacteria (PNSB), rubber sheet wastewater, single cell protein (SCP).

Abbreviations: BOD: biochemical oxygen demand

COD: chemical oxygen demand

OD: optical density

OW: optimized wastewater

PNSB: purple non sulphur photosynthetic bacteria

ROW:raw optimized wastewater

RW: raw wastewater

SCP: single cell protein

SEM: scanning electron microscope

SOW: sterile optimized wastewater

SW: sterile wastewater

TEM: transmission electron microscope

TKN: total kjeldahl nitrogen

VFAs: volatule fatty acids

YE: yeast extract

A total of 92 isolates of the purple non sulphur photosynthetic bacteria (PNSB) were isolated from 23 samples of wastewater obtained from rubber sheet manufacturing processes from various places of southern, Thailand. The isolate DK6 had the best potential for use in wastewater treatment as it can outcompete indigenous strains of PNSB when grown with them under conditions of microaerobic-light conditions. The isolate DK6 was identified as being most closely allied to Rhodopseudomonas blastica. The optimal pH and temperature for cell growth were between 6.5-7.5 and $30^{\circ} \mathrm{C}$, respectively. Optimum growth of DK6 was obtained after supplementing the wastewater from a latex rubber sheet processing plant with $0.50 \%$

\footnotetext{
* Corresponding author
} 
$\left(\mathrm{NH}_{4}\right) 2 \mathrm{SO}_{4}$ and $1 \mathrm{mg} / \mathrm{L}$ nicotinic acid under conditions of microaerobic-light (3000 lux). Using these optimum conditions for growth, indigenous microorganisms reduced the initial chemical oxygen demand (COD) of the wastewater from 7,328 to $3371 \mathrm{mg} / \mathrm{L}$ a reduction of $54 \%$ and the biochemical oxygen demand (BOD) (initial BOD $4967 \mathrm{mg} / \mathrm{L}$ ) by $70 \%$. Using the same conditions and either a pure culture of DK6 or a mixed culture (DK6 plus indigenous microorganisms) a reduction of $90 \%$ of both COD and BOD was achieved. Chemical analysis of the cultures after treatment of the enriched wastewater shows that the protein content of the pure DK6 was $65.2 \%$ of the dry weight, and in mixed culture the protein content was $66.7 \%$. Hence, single cell protein (SCP) may be a possible bi- product of the treatment process.

Anoxygenic phototrophic bacteria, especially purple non sulphur photosynthetic bacteria (PNSB) are widely distributed in soil, water, and wastewater (Holt et al. 1994; Zhu et al. 2002; Hoogewerf et al. 2003). PNSB are versatile organisms as they can grow as both photoautotrophs and photoheterotrophs under anaerobic-light or microaerobiclight conditions (Holt et al. 1994). They also can grow anaerobically in the dark using fermentation and many can grow aerobically in darkness using respiration (Holt et al. 1994). These PNSB can use various substrates as sources of carbon and energy with ammonium and/or nitrate as a source of nitrogen and may use sulphide or thiosulphate as an electron donor under photosynthetic conditions (Imhoff and Trüper, 1989). Because of these properties, they have potential for treating various sources of wastewater. In addition, PNSB biomass is rich in protein with good quantities of essential amino acids, vitamins and carotenoids. Therefore, single cell protein (SCP) may be a bi-product of wastewater treatment and be used for animal feed (Sasikala and Ramana, 1995; Prasertsan et al. 1997; Ponsano et al. 2002).

Rubber sheet processing plants are widely distributed throughout the southern and eastern parts of Thailand. Wastewater from rubber sheet processing contains both organic and inorganic matter that originated from natural latex rubber and from chemicals used in processing, such as ammonia, formic acid, sodium metabisulphite and sodium sulphite. The plants commonly use lagoons or oxidation ponds for wastewater treatment. This treatment is a low cost operation but produces hydrogen sulphide, and the rotten-egg odour is a major problem of the system. Many researchers have found that certain PNSB species from the genera Rhodopseudomonas, Rhodobacter and Rhodospirillum can eliminate the $\mathrm{H}_{2} \mathrm{~S}$ odour nuisance from the facultative ponds of waste stabilization ponds due to their abilities to oxidize sulphide to sulphate using light during photolithoautotrophic growth (Veenstra et al. 1995; Tadesse et al. 2003; Kim et al. 2004). The reddish-pink colour bloom of PNSB occurs occasionally in anaerobic or oxidation ponds of latex rubber wastewater treatment systems and in particular those treating effluent from the rubber sheet manufacturing process. This means that some PNSB have a potential for use in the treatment of latex rubber wastewater under appropriate conditions. Therefore, the aims of this study were to screen for a strain of PNSB with this potential and to determine the optimum conditions for this strain to be most effective in treating rubber sheet wastewater.

\section{MATERIALS AND METHODS}

\section{Enrichment for PNSB}

A total of 23 wastewater samples from the wastewater treatment system of rubber sheet manufacturing processes were collected from various factories in southern Thailand. $5 \mathrm{ml}$ of each sample was inoculated into $5 \mathrm{ml}$ of double strength G-5 broth (Ormerod et al. 1961) for isolating PNSB and incubated at room temperature $\left(28-32^{\circ} \mathrm{C}\right)$ under anaerobic-light conditions. To achieve anaerobic-light conditions, $1 \mathrm{~cm}$ of sterile liquid paraffin was added to the top of the growth medium held in a test tube with a light intensity of 3500 lux, generated by a 100 watt incandescent lamp for between 48 and 96 hrs. The light intensity was measured using Denki light meter model DK-211. The lighting system used provided an incubation temperature in a range of $31-35^{\circ} \mathrm{C}$ depending on the ambient temperature, and this light condition was used for later studies, unless otherwise stated. Purification of single colonies was

Table 1. Growth of 69 cultures of PNPB, isolated from latex rubber sheet wastewater processes, on different wastewater media using microaerobic-light conditions after $72 \mathrm{hrs}$ cultivation.

\begin{tabular}{|c|c|c|c|c|}
\hline \hline OD 660 nm & Sterile wastewater (SW) & SW +0.10\% YE & Raw wastewater (RW) & RW +0.10\% YE \\
\hline \multicolumn{5}{|c|}{ Numbers of isolates that grew to the designated OD600 } \\
\hline$>0.10-0.15$ & 14 & 0 & 23 & 0 \\
\hline$>0.15-0.20$ & 31 & 0 & 30 & 0 \\
\hline$>0.20-0.25$ & 20 & 0 & 9 & 0 \\
\hline$>0.25-0.30$ & 2 & 0 & $1(\mathrm{DK} 6)$ & 0 \\
\hline$>0.30-0.40$ & 2 (DK1, DK6) & 0 & 0 & 18 \\
\hline$>0.40-0.60$ & 0 & 12 & 0 & 25 \\
\hline$>0.60-0.80$ & 0 & 19 & 0 & 20 \\
\hline$>0.80-1.00$ & 0 & 30 & 0 & 6 \\
\hline$>1.00$ & 0 & 8 & & 0 \\
\hline
\end{tabular}

* The $\mathrm{OD}_{600}$ obtained after $72 \mathrm{hrs}$, without inoculation, was always $<0.10$. 
achieved by successive re-streaking on G-5 medium containing $1.5 \%$ agar and incubated with the same conditions.

\section{Inoculum production for characterizing the isolates}

One loopful of each isolate was transferred to a screw cap test tube ( 25 x $150 \mathrm{~mm}: 49 \mathrm{ml}$ ) containing $45 \mathrm{ml} \mathrm{G}-5$ broth which left a small space on the top of the medium to obtain microaerobic condition and cultures were incubated with the usual light conditions for 24-48 hrs. For use as an inoculum cell suspensions of each isolate were adjusted to an optical density (OD) of 0.5 at $660 \mathrm{~nm}$ using the sterile G-5 medium as diluent. The sterile G-5 medium was also used as the blank.
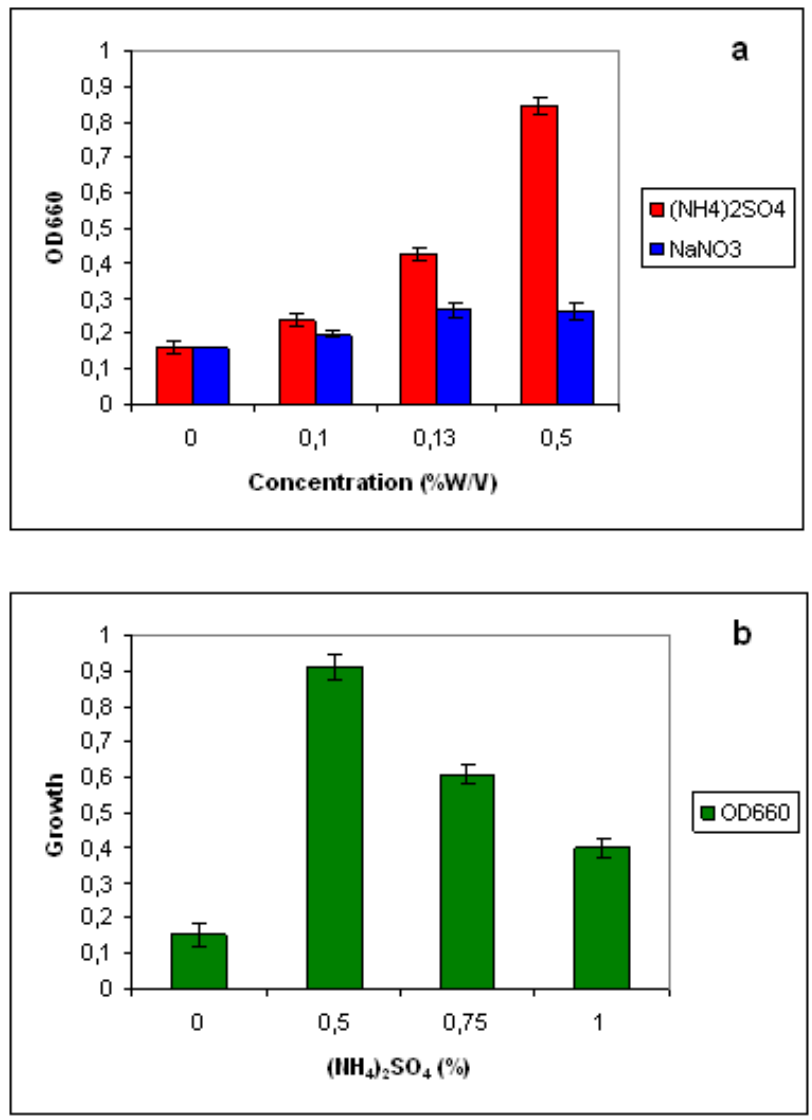

Figure 1. Effects of nitrogen source and their initial concentrations on the growth of the isolate DK6 in rubber sheet wastewater with microaerobic-light conditions for 72 hrs. Each point represents the mean of three replicates \pm standard error of mean

(a) Source of nitrogen.

(b) Added (NH4)2SO4 on bacterial growth.

\section{Wastewater test medium}

Wastewater from a latex rubber sheet process plant at Yang-Ngam in the Hat-Yai district of Songkhla province was collected. At Yang-Ngam a series of three lagoons are used for the wastewater treatment system, and water temperatures in these lagoons vary between $28-34^{\circ} \mathrm{C}$ depending on sunlight. Wastewater from the first lagoon was collected for this study because it caused an odorous $\left(\mathrm{H}_{2} \mathrm{~S}\right)$ nuisance. The properties of the wastewater varied at each collecting time. However, the chemical oxygen demand (COD) level was between 5800 and $8000 \mathrm{mg} / \mathrm{L}$ and the total Kjeldahl nitrogen (TKN) level was between 20-35 mg/L. Volatile fatty acids (VFAs) were present with acetic acid at concentrations between 430 and $650 \mathrm{mg} / \mathrm{L}$ and the $\mathrm{pH}$ varied from 7.5 to 7.8 . TKN and VFAs were determined according to the APHA, AWWA and WPCF (1998), and a $\mathrm{pH}$ meter was used to measure $\mathrm{pH}$. The collected wastewater was centrifuged at 6455 (RCF x $g$ ) for $15 \mathrm{~min}$ followed by autoclaving at $121^{\circ} \mathrm{C}(15 \mathrm{lb} / \mathrm{sq}$. inch) for 15 min to achieve sterile conditions prior to use as the growth medium.

\section{Isolation of PNSB}

To select a strain that has the potential for use in the field, two steps of selection were conducted. Primary screening consisted of selecting isolates that had grown to an $\mathrm{OD}_{660}$ of greater than 0.10 after $96 \mathrm{hrs}$ incubation in sterile wastewater medium under microaerobic-light conditions. Secondary screening consisted of distinguishing isolates that showed growth in each of the following 4 growth media after 72 hrs in test tubes under microaerobic-light conditions: (1) sterile wastewater (SW), (2) SW plus $0.10 \%$ yeast extract (YE), (3) raw wastewater (RW: non autoclaved wastewater), and (4) RW plus 0.10\% YE. Each selected isolate of PNSB was inoculated into each medium as a $10 \% \mathrm{v} / \mathrm{v}$ inoculum from a culture growing in G-5 medium.

\section{Bacterial identification}

A selected isolate, DK6, that had passed both screening tests was characterized using both morphological and physiological properties and identified according to Bergey's Manual of Systematic Bacteriology vol. 3 (Imhoff and Trüper, 1989) and also Bergey's Manual of Determinative Bacteriology $9^{\text {th }}$ ed. (Holt et al. 1994). The basal minimal medium of Ormerod et al. (1961) contained biotin $(10 \mu \mathrm{g} / \mathrm{L})$, thiamine-HCl $(1 \mathrm{mg} / \mathrm{L}), p$-aminobenzoic acid (1 mg/L), and nicotinic acid (1 mg/L), but ammonium sulphate and malate were omitted and therefore it initially contained neither a nitrogen nor electron donor source. To test for the utilization of various organic substrates the basal medium was supplemented with $10 \mathrm{mM}$ of organic substrate and $10 \mathrm{mM}$ of ammonium sulphate. To test for the utilization of sulphide or thiosulphate as an electron donor, the basal medium was supplemented with ammonium sulphate, sodium bicarbonate, and sodium sulphide or sodium thiosulphate each at a final concentration of 10 $\mathrm{mM}$. To test for nitrate as a sole source of nitrogen $10 \mathrm{mM}$ of both malate and $\mathrm{NaNO}_{3}$ were added to the basal medium. The requirement for each vitamin present in the basal medium was also investigated. Gelatin liquefaction was examined with G-5 medium containing $12 \%$ (w/v) 
gelatin. All media before autoclaving were adjusted to $\mathrm{pH}$ 6.8, except for the G-5 medium, which was adjusted to $\mathrm{pH}$ 7.0. For pre-incubation and stock cultures, G-5 medium was used. Cultures were grown with anaerobic conditions and illumination (ca. 3500 lux) as previously described. Cell morphology was examined with a scanning electron microscope, model JSM-5800LV, JEOL. Internal photosynthetic membranes were identified using a transmission electron microscope, JEM-2010, JEOL. The protocols used for scanning electron microscope (SEM) and transmission electron microscope (TEM) followed the instruction manuals for the instruments. Whole cell pigment scans were performed using cell pellets resuspended in $60 \%$ sucrose (Pfennig, 1969). Scans were performed on a Hitachi model UV-visible recording spectrophotometer. As the isolate DK6 will be used as an inoculum for rubber sheet wastewater treatment, the effect of $\mathrm{pH}$ was investigated in G-5 medium by varying the $\mathrm{pH}$ to $5.0,5.5$, 6.0, 6.5, 7.0, 7.5, 8.0, 8.5 and 9.0 and measuring the growth under microaerobic-light conditions after 72 hrs incubation. The optimum growth temperature was determined in G-5 medium with an initial $\mathrm{pH}$ of 7.0 by varying the temperature between $25,30,35$ and $40^{\circ} \mathrm{C}$.

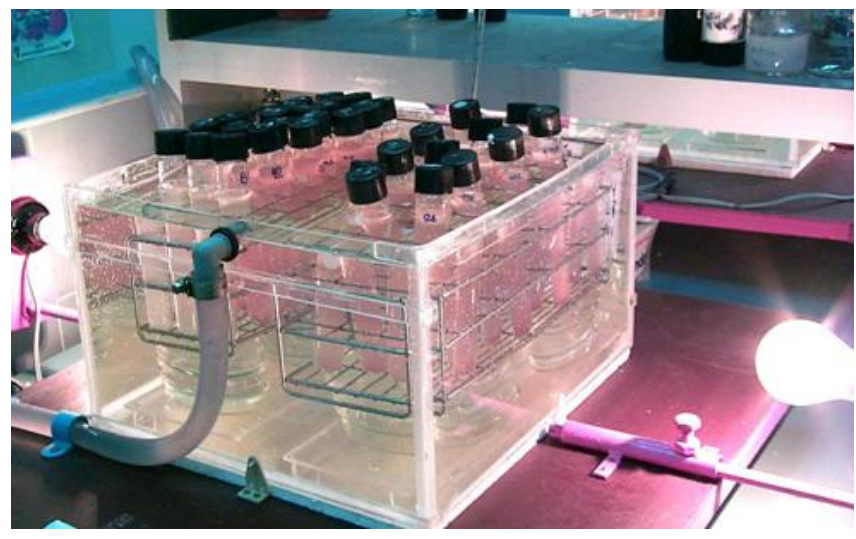

Figure 2. Cultivation of purple nonsulphur photosynthetic bacteria (the isolate DK6) in optimized rubber sheet wastewater under microaerobic-light $(3000$ lux $)$ at $30^{\circ} \mathrm{C}$ with water circulation for cooling.

\section{Optimizing wastewater composition incubation conditions} and

Microaerobic-light conditions were used for all experiments to make conditions as close as possible to those of a natural system of rubber wastewater treatment.

Effect of added nitrogen source. $\mathrm{NaNO}_{3}$ or $\left(\mathrm{NH}_{4}\right)_{2} \mathrm{SO}_{4}$ were added to SW medium at concentrations that varied from $0,0.10,0.134$ and $0.50 \%$. The wastewater $\mathrm{pH}$ of 7.5 was not adjusted as the optimum $\mathrm{pH}$ of the isolate DK6 was in the range of 6.5-7.5. $\left(\mathrm{NH}_{4}\right)_{2} \mathrm{SO}_{4}$ being the best nitrogen source, (Figure 1a), was then tested at higher concentrations that varied from $0,0.50,0.75$ and $1.00 \%$. In all cases SW medium was used with microaerobic-light condition for 72 hrs.
Table 2. Morphological and physiological characteristics of isolate DK6 grown with anaerobic-light conditions at $30^{\circ} \mathrm{C}$ and modifications to the basal minimal medium of Ormerod et al. (1961).

\begin{tabular}{|c|c|c|}
\hline Characteristic & DK6 & $\begin{array}{c}\text { Rhodopseudomonas } \\
\text { blastica }^{a}\end{array}$ \\
\hline $\begin{array}{l}\text { Colour of culture } \\
\text { (anaerobic-light) }\end{array}$ & red & red \\
\hline $\begin{array}{l}\text { Colour of culture } \\
\text { (aerobic-dark) }\end{array}$ & white & white to pink \\
\hline Cell shape & short rod & rod \\
\hline Gram staining & negative & negative \\
\hline Motility & non motile & non motile \\
\hline Biotin & require & require \\
\hline Nicotinic acid & require & require \\
\hline p-aminobenzoic acid & require & require \\
\hline Thiamine hydrochloride & require & require \\
\hline $\mathrm{pH}(5-9)$ & growth & 0 \\
\hline Optimum pH & $6.5-7.5$ & $6.5-7.5$ \\
\hline Temperature $\left(25-45^{\circ} \mathrm{C}\right)$ & growth & 0 \\
\hline Optimum temperature & $30^{\circ} \mathrm{C}$ & $30-35^{\circ} \mathrm{C}$ \\
\hline Acetate & + & + \\
\hline Arginine & - & 0 \\
\hline Benzoate & - & - \\
\hline Butyrate & + & + \\
\hline Caproate & + & 0 \\
\hline Citrate & + & + \\
\hline Ethanol $^{b}$ & + & - \\
\hline Formate & - & - \\
\hline Fructose & + & + \\
\hline Fumarate & + & + \\
\hline Glucose & + & + \\
\hline Gluconate & - & 0 \\
\hline Glycerol & + & + \\
\hline Glycolate & - & - \\
\hline Gelatin & + & + \\
\hline Lactate & + & + \\
\hline Malonate & + & 0 \\
\hline Methanol & - & - \\
\hline Mannitol & + & + \\
\hline Nitrate & + & 0 \\
\hline Propionate & + & + \\
\hline Pyruvate & + & + \\
\hline Succinate & + & + \\
\hline Sulfide & - & - \\
\hline Thiosulfate $^{b}$ & + & - \\
\hline Sorbitol & + & + \\
\hline Tartrate & - & - \\
\hline
\end{tabular}

$+=$ utilized

- = not utilized

$0=$ not determined

$a=$ Code from Imhoff and Truper, 1989

$\mathrm{b}=$ substrate in respect of which the utilization by DK6 and Rhodopseudomonas blastica differs

Effects of those vitamins present in the basal medium. SW medium supplemented with an optimal concentration $(0.5 \%)$ of $\left(\mathrm{NH}_{4}\right)_{2} \mathrm{SO}_{4}$ was used (Figure 1) as the base control. Treatments included the control plus basal medium and one of the modified basal media as follows: $0.01 \mathrm{mg} / \mathrm{L}$ biotin, $1 \mathrm{mg} / \mathrm{L}$ nicotinic acid, $1 \mathrm{mg} / \mathrm{L} p$-aminobenzoic acid, $1 \mathrm{mg} / \mathrm{L}$ thiamine hydrochloride. As YE is a complex natural material with high vitamin B levels, it was also tested for its 
effect on growth at $0.10 \%$. The optimum concentration of nicotinic acid for growing cells was further examined by adding $0,1.00,1.50$ and $2.00 \mathrm{mg} / \mathrm{L}$ to the basal medium. All cultures were grown for 72 hrs with microaerobic-light conditions.

Effect of light and temperature. The effect of light intensity was investigated by growing DK6 in optimized wastewater (OW: wastewater was amended with $0.5 \%$ $\left.\mathrm{NH}_{4}\right)_{2} \mathrm{SO}_{4}$ and $1.0 \mathrm{mg} / \mathrm{L}$ nicotinic acid) under light intensities of 3000, 3500 and 4000 lux. These variations were obtained by adjusting the distances between light sources and culture tubes. At each light intensity the effect of temperatures of 30,35 and $40^{\circ} \mathrm{C}$ were also tested.

Table 3. Effects of supplementing the rubber sheet wastewater medium with vitamins or YE on the growth of the isolate DK6 under microaerobic-light conditions at $30^{\circ} \mathrm{C}$.

\begin{tabular}{|c|c|c|}
\hline Supplementation & $\begin{array}{c}\text { Concentration } \\
(\mathbf{m g} / \mathbf{L})\end{array}$ & $\begin{array}{c}\text { Growth } \\
\text { (OD 660 } \mathbf{~ n m})\end{array}$ \\
\hline No supplement (Control) & 0 & 1.55 \\
\hline Biotin & 0.01 & 1.18 \\
\hline Nicotinic acid & 1 & 1.79 \\
\hline P-aminobenzoic acid & 1 & 1.63 \\
\hline Thiamine hydrochloride & 1 & 1.07 \\
\hline Yeast extract & 1000 & 2.00 \\
\hline Basal medium & Ormerod et al. 1961 & 1.17 \\
\hline
\end{tabular}

\section{Changes in optimized wastewater after inoculation with PNSB strain DK6}

A test tube $(25 \times 150 \mathrm{~mm})$ with the screw cap in place to prevent volatilization was used as the culture vessel. Four treatments were set as follows: sterile OW as a control with no inoculum sterile optimized wastewater (SOW); SOW plus $10 \%$ inoculum (SOW + DK6); raw OW (raw optimized wastewater (ROW): non autoclaved optimized wastewater); ROW plus 10\% inoculum (ROW + DK6). ROW contains indigenous organisms. The culture vessels were placed in a transparent plastic chamber in which the temperature $\left(30^{\circ} \mathrm{C}\right)$ was controlled by using water circulation, and were illuminated at 3000 lux with $60 \mathrm{~W}$ incandescent lamps, as shown in Figure 2. Parameters (growth, $\mathrm{pH}$, biochemical oxygen demand (BOD), and COD) were monitored at the start $(t=0)$ and the end $(4$ days) of the experiment. Bacterial growth was measured as $\mathrm{OD}$ at $660 \mathrm{~nm}$ by a spectrophotometer and $\mathrm{pH}$ using a $\mathrm{pH}$ meter. After 4 days cell suspensions were centrifuged at 6455 (RCF x g) for $20 \mathrm{~min}$ and cell pellets were used for investigations of dry weight and chemical composition (protein, carbohydrate, lipid and ash, AOAC, 2002). The culture supernatant was used for determination of BOD (Azide modification method) and COD (Dichromate reflux method) (APHA, AWWA, and WPCF, 1998). Biomass productivity was calculated from the total volume of wastewater used and the total weight of biomass produced in the process, after 4 days of cultivation. All experiments were conducted in triplicate and averages reported.
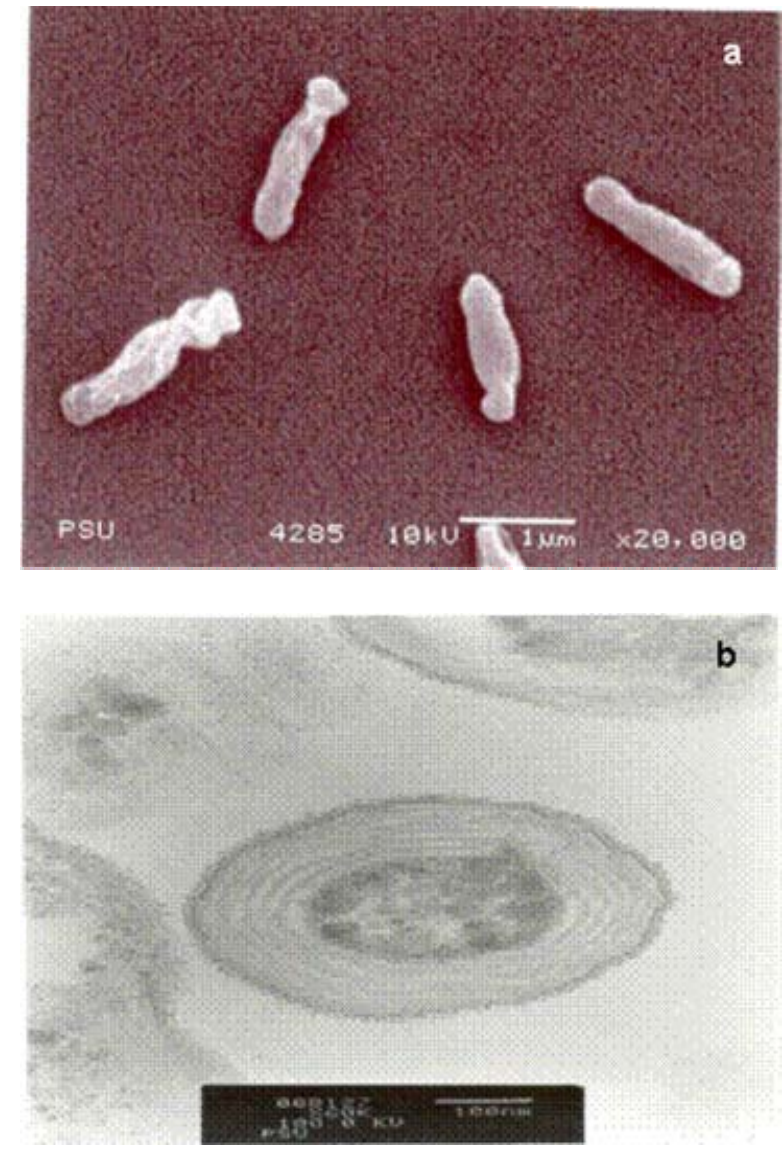

Figure 3. Rhodopseudomonas sp. DK6 grown in G-5 broth under microaerobic-light conditions.

(a) Scanning electron microscope (SEM) photomicrograph of the isolate DK6, showing budding.

(b) Transmission electron microscope (TEM) photomicrograph of the isolate DK6 showing internal photosynthetic membranes parallel to the cell membrane.

\section{RESULTS}

\section{Isolation and selection of PNSB}

With anaerobic-light conditions and G-5 medium (water sample/medium = 1:1), with malate is a sole source of carbon, 92 isolates of PNSB were readily isolated from 23 samples of rubber sheet wastewater medium. 69 isolates that grew with microaerobic-light conditions after a 96 hrs incubation period, were selected for further screening due to their growth exceeding an $\mathrm{OD}_{660}$ of 0.10 in sterile rubber sheet wastewater medium without the addition of any nutrients (Table 1). After a 72 hrs incubation many isolates of PNSB grew well with an $\mathrm{OD}_{660}>0.80$ in a medium supplemented with $0.10 \%$ YE either in sterile wastewater $(\mathrm{SW}+0.10 \% \mathrm{YE})$ or in raw (non autoclaved) wastewater 
(RW $+0.10 \% \mathrm{YE})$. Without the supplement of YE both in the SW and the RW, only isolates DK1 and DK6 gave growth $>0.30 \mathrm{OD}_{600}$. However, only the isolate DK6 was selected for further studies as it was the one isolate that also produced growth $>0.30 \mathrm{OD}_{600}$ in the raw unsupplemented wastewater in competition with the indigenous organisms.

\section{Characterization of strain DK6}

The isolate DK6 was a non motile, Gram negative, short rod, $0.25 \mu \mathrm{m}$ wide and $1.50 \mu \mathrm{m}$ long and multiplied by budding (Figure 3a). Internal photosynthetic membranes, appeared as lamella, lying parallel to the cytoplasmic membrane (Figure 3b). After growth under anaerobic-photo heterotrophic conditions cell suspensions were red and the absorption spectra of a living cells suspension showed the maxima of bacteriochlorophyll a (331, 375, 590, 805 and 872) (Imhoff and Trüper, 1989) as shown in Figure 4. These properties identify the isolate DK6 as Rhodopseudomonas sp. (Imhoff and Trüper, 1989). The isolate DK6 grew with organic compounds or thiosulphate in a basal medium and either $\left(\mathrm{NH}_{4}\right)_{2} \mathrm{SO}_{4}$ or $\mathrm{NaNO}_{3}$ as a nitrogen source anaerobically in the light (Table 2). All of the vitamins of the basal medium were necessary for growth. With photo heterotrophic conditions DK6 used acetate, butyrate, caproate, citrate, ethanol, fructose, glucose, fumarate, gelatine, glycerol, lactate, malonate, mannitol, propionate, pyruvate, sorbitol, and succinate. Thiosulphate was used as an electron donor under photoautotrophic conditions. The results indicate that the isolate DK6 was most closely allied to Rhodopseudomonas blastica although Rps. blastica has not been shown to utilize ethanol and thiosulphate under anaerobic light conditions (Imhoff and Trüper, 1989).

\section{Determination of the optimum conditions for growth of isolate DK6 in wastewater medium}

Effect of nitrogen source. Supplements of nitrogen to SW, in the form of either $\left(\mathrm{NH}_{4}\right)_{2} \mathrm{SO}_{4}$ or $\mathrm{NaNO}_{3}$ produced better growth of the isolate DK6 under microaerobic-light conditions than SW with no added nitrogen source (Figure 1a). More growth was obtained with ammonium ion than with nitrate ion, and the optimum ammonium ion concentration was $0.50 \%$ (5 g/L); with higher levels retarding growth (Figure $1 \mathrm{~b}$ ).

Effect of vitamins. Over 72 hrs of cultivation with microaerobic-light conditions the best growth of the isolate DK6 was observed in SW with YE added at $1 \mathrm{~g} / \mathrm{L}\left(\mathrm{OD}_{660}=\right.$ 2.00). Addition of nicotinic acid to a concentration of 1 $\mathrm{mg} / \mathrm{L}$ increased the $\mathrm{OD}_{660}$ at the end of cultivation to 1.79 from 1.55 for the control, but higher concentrations had no additional effect (Figure 5). Supplementing with $p$ aminobenzoic acid to a concentration of $1 \mathrm{mg} / \mathrm{L}$ increased the $\mathrm{OD}_{660}$ to 1.63 (Table 3 ). In contrast, the addition of biotin $(0.01 \mathrm{mg} / \mathrm{L})$ or thiamine hydrochloride $(1 \mathrm{mg} / \mathrm{L})$ or all vitamins together as detailed in Table 3 reduced growth.

Effect of light intensity and temperature. The best growth was observed at $30^{\circ} \mathrm{C}$ and 3000 lux (data not shown). As increasing light intensity could increase the temperature, in further experiments the temperature of the incubations was controlled by the circulation of water.

The conditions chosen for growing the isolate DK6 in wastewater were therefore as follows: wastewater, either sterile (SOW) or non autoclaved (ROW), supplemented with $0.5 \%$ ammonium sulphate and $1 \mathrm{mg} / \mathrm{L}$ nicotinic acid with a final $\mathrm{pH}$ of 7.6 and incubation at $30^{\circ} \mathrm{C}$ and a light intensity of 3000 lux.

\section{Growth of DK6 with and its effect on optimized wastewater}

SOW and ROW were incubated for 4 days with and without an inoculum of DK6. The best growth (OD $\left.\mathrm{OD}_{660} 1.60\right)$ was observed with ROW + DK6 and appeared as a red cell suspension. SOW + DK6 also produced a red suspension but with a final $\mathrm{OD}_{660}$ of 1.40 . No growth was observed

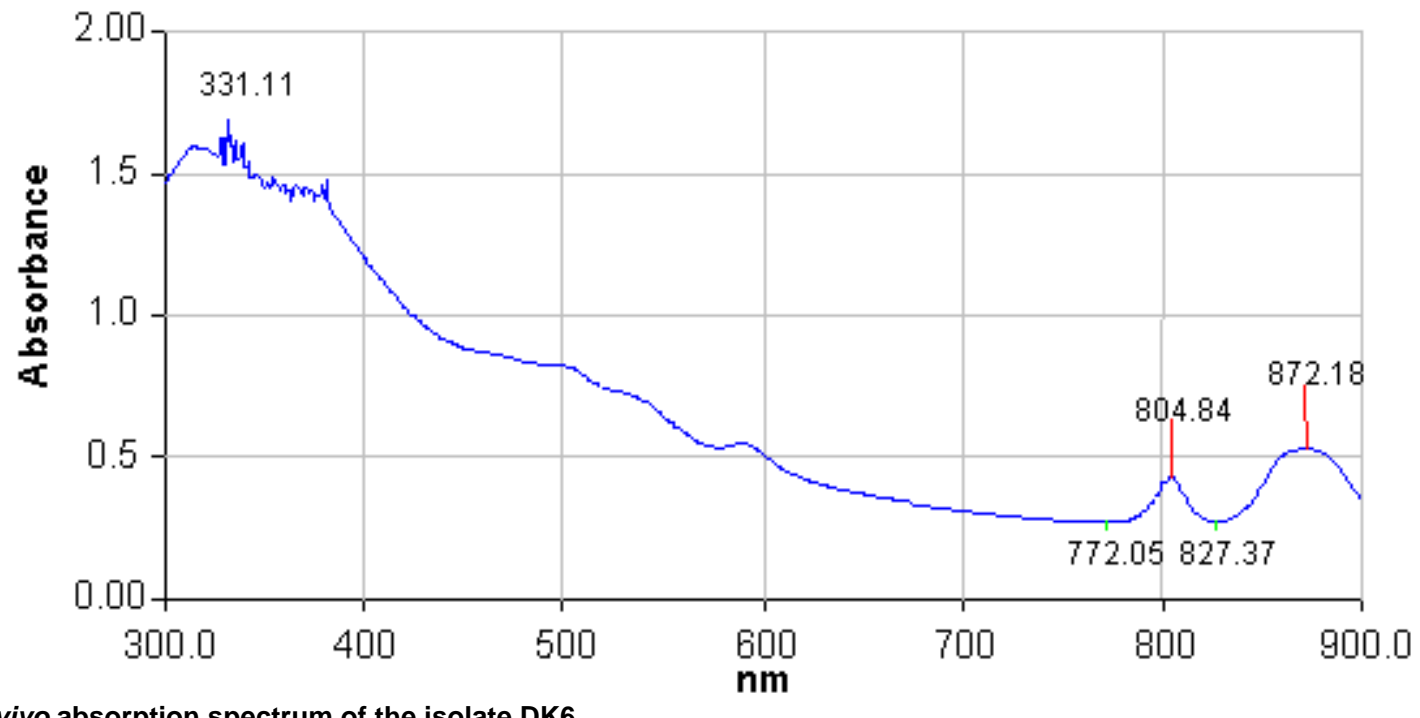

Figure 4. In vivo absorption spectrum of the isolate DK6. 
with SOW, (final $\mathrm{OD}_{660}$ of 0.09) and ROW containing only indigenous organisms gave a relatively poor growth of a pink suspension and final $\mathrm{OD}_{660}$ of 0.60 (Figure 6a). All treatments including a control had a similar final $\mathrm{pH}$ of about 8.5 although the initial $\mathrm{pH}$ values were between 7.547.97 (Figure 6b). A 6\% reduction of BOD was found in SOW indicating that some abiotic degradation could occur. With ROW the indigenous microbes produced a $70 \%$ reduction of $\mathrm{BOD}$ and a $54 \%$ reduction of COD. In contrast, cultivation of the isolate DK6 in either the presence or absence of the indigenous microbes produced a $90 \%$ reduction of both BOD and COD (Figure 6c).

There were slight but, apart from the lipid component, probably insignificant differences in the chemical composition of the cell material isolated from SOW + DK6 and ROW + DK6. With the pure culture of DK6 the chemical composition of sedimented cells was $65.2 \%$ protein, $28.8 \%$ total carbohydrate, $5.6 \%$ ash and $0.4 \%$ lipid, whereas with the material containing indigenous microbes the composition was $66.7 \%$ protein, $26.3 \%$ total carbohydrate, $5.4 \%$ ash and $1.6 \%$ lipid. Process productivity based on the 4 days of cultivation was 0.10 g/L.day for a pure culture of DK6 and 0.24 g/L.day for a mixed culture of the isolate DK6 and indigenous microbes.

Table 4. Chemical composition of cells collected from cultures of strain DK6, grown for $96 \mathrm{hr}$ with optimized rubber sheet wastewater medium, in the presence and absence of indigenous microbes.

\begin{tabular}{|l|c|c|}
\hline $\begin{array}{c}\text { Composition } \\
\text { (\%) dry weight }\end{array}$ & Pure culture & Mixed culture \\
\hline Crude protein & 65.2 & 66.7 \\
\hline Total carbohydrate & 28.8 & 26.3 \\
\hline Lipid & 0.4 & 1.6 \\
\hline Ash & 5.6 & 5.4 \\
\hline
\end{tabular}

\section{DISCUSSION}

\section{Selection and identification}

Due to the finding that 75\% (69/92) of PNSB isolates were able to grow with microaerobic illuminated conditions in sterile rubber sheet wastewater it may be assumed that rubber sheet wastewater contains some bioavailable electron donating substrates for growth. This was confirmed when PNSB were easily isolated from a number of rubber sheet wastewater treatment processes. However, without the addition of YE only two isolates showed fair growth ( $\mathrm{OD}_{660}$ 0.30-0.40) in SW (isolates: DK1 and DK6) and only one in raw wastewater (DK6) (Table 1). Hence, the isolate DK6 had a potential for use as an inoculum for rubber sheet wastewater treatment. According to the results shown in Table 1 in order to treat wastewater, additional nutrients need to be added to the wastewater to stimulate the growth of the microbes, including the isolate DK6.
As a result of the identification procedures isolate DK6 was most closely allied to Rhodopseudomonas blastica. Many of the substrates used by isolate DK6 as a sole source of carbon and electron donor such as acetate, butyrate, lactate, propionate, succinate, ethanol (Table 2) are usually found in anaerobic systems (Bitton, 1994; Izu et al. 2001). In addition, the bacterium used thiosulphate but not sulphide as an electron donor for photoautotrophic growth and ammonium or nitrate was used as a nitrogen source. The optimum $\mathrm{pH}$ (6.5-7.5) and temperature $\left(30^{\circ} \mathrm{C}\right)$ for the isolate DK6 were similar to the conditions found in lagoons of rubber sheet wastewater treatment systems i.e. a pH of 6.5-7.7 and temperatures between $28-34^{\circ} \mathrm{C}$. Isolate DK6, is therefore suitable for testing its ability to treat rubber sheet wastewater.

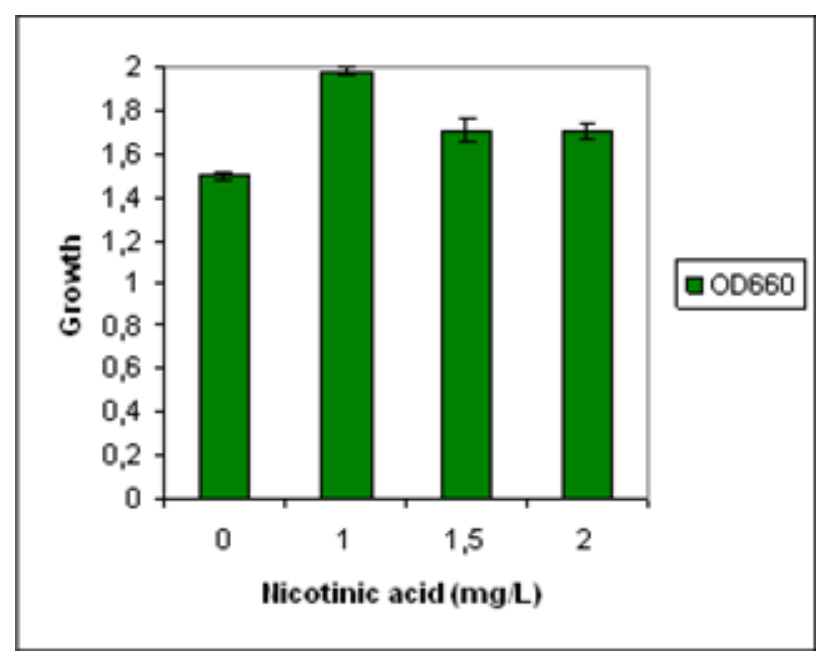

Figure 5. Effect of initial nicotinic acid concentration on growth of the isolate DK6 with microaerobic-light conditions after a $72 \mathrm{hrs}$ incubation period. Each point represents the mean of three replicates \pm standard error of mean.

\section{Wastewater treatment using the isolate DK6}

The ability to use either ammonium or nitrate for growth (Table 2) is an advantage because during wastewater treatment organic nitrogen is first converted to ammonium then if conditions are suitable oxidized by nitrifying bacteria to nitrate. Hence in a case when ammonium becomes growth limiting the bacterium could continue to grow with nitrate. Reduction of the total amount of nitrogen in wastewater prior to discharge into a natural body of water can prevent eutrophication (Atlas and Bartha, 1998; Sawayama et al. 2000). Rubber sheet wastewater has an initial TKN of between 20-35 mg/L.

DK6 required the vitamins (biotin, $p$-aminobenzoic acid, nicotinic acid and thiamine hydrochloride) to be present in the basal medium (Table 2) but only nicotinic acid and $p$ aminobenzoic acid stimulated growth in the rubber sheet wastewater (Table 3). Both biotin and thiamine hydrochloride retarded growth. Obviously these vitamins 
must be present in the wastewater and the reasons for the observed growth inhibition are not clear. YE added at 1000 $\mathrm{mg} / \mathrm{L}$ caused the best stimulation with an increase of $\mathrm{OD}_{660}$ from 1.55 to 2.00. Although YE contains many B vitamins it may also act as a source of nitrogen. The effect on growth of YE added to ammonium supplemented wastewater was not tested. In view of the difference in costs of adding 1 $\mathrm{mg} / \mathrm{L}$ of nicotinic acid and $100 \mathrm{mg} / \mathrm{L}$ of YE, nicotinic acid was chosen as the stimulating vitamin.
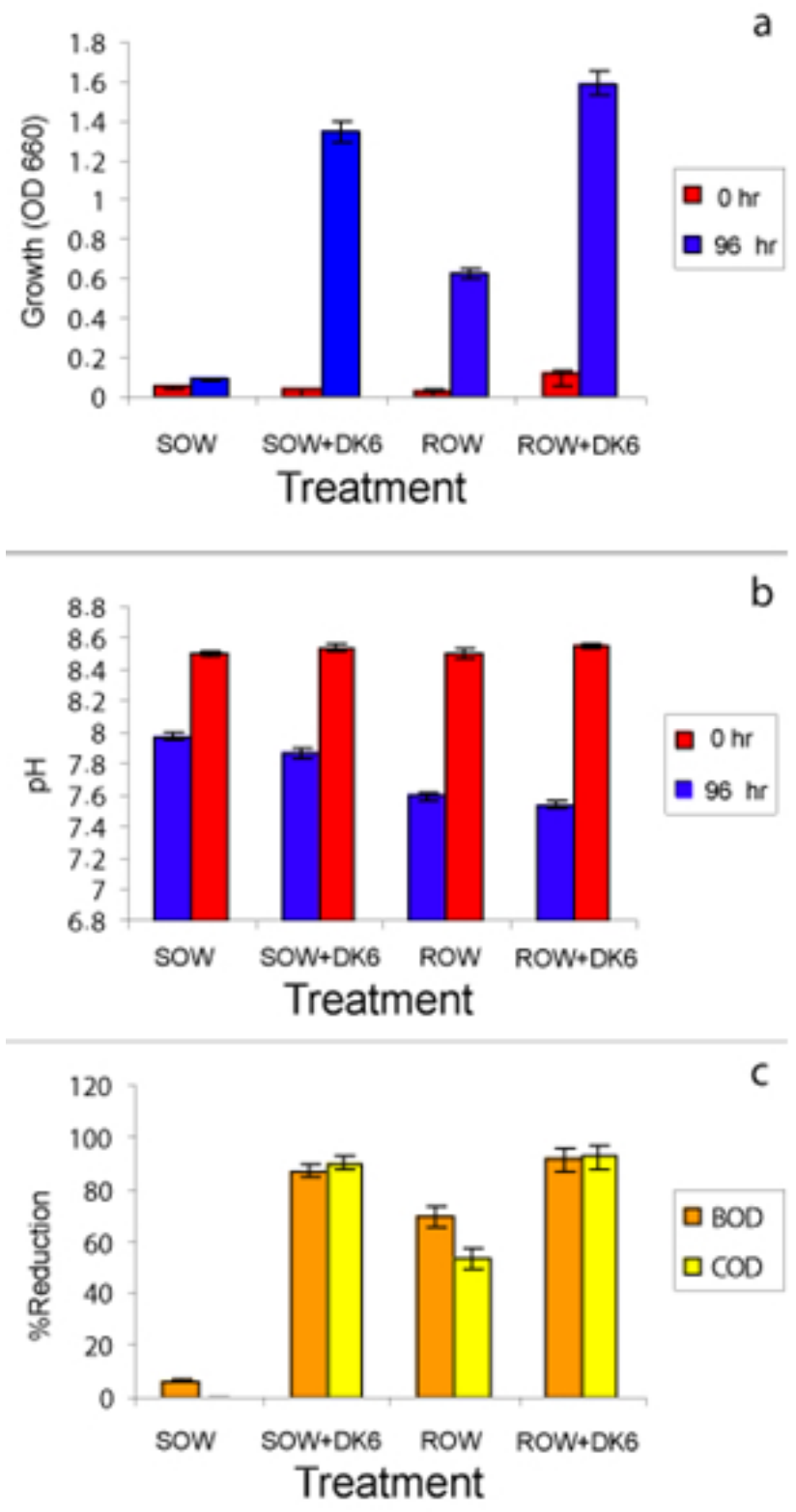

Figure 6. Growth of the isolate DK6 in optimized rubber sheet wastewater and optimized conditions for $96 \mathrm{hrs}$ incubation and its effect on the medium, pH, BOD and COD. Each point represents the mean of three replicates \pm standard error of mean.

(a) Bacterial growth.

(b) Change of $\mathrm{pH}$.

(c) Reduction of BOD and COD.
Although no microorganisms were detected in SOW after the 96 hrs incubation there was a small increase in turbidity (Figure 6a). Some of this could have been due to photooxidation of some substances that has been shown to occur in natural waters such as humic acid, volatile organic compounds, phenol and so on, that resulted in some precipitation (Hu et al. 2001; Koh et al.2004; Talu and Diyamandoglu, 2004). However it is more likely due to an increase in the $\mathrm{pH}$ from 7.9 to 8.5 again causing some precipitation. The reasons for this increase in $\mathrm{pH}$, to roughly 8.5 , in all 4 media, even though the $\mathrm{pH}$ values at the start of the incubation were different, are not clear. Some increase was observed after autoclaving SW from 7.5 to 7.9 (Figure 6b). Addition of ammonium sulphate also raised the $\mathrm{pH}$ from 7.53 to 7.6. Autoclaving could have caused volatilization of fatty acids or $\mathrm{H}_{2} \mathrm{~S}$ as the Teflon screw caps were at that stage only loosely closed. At an initial $\mathrm{pH}$ of 7.5 any anion either organic or inorganic acid such as acetate or sulphate or nitrate present in the wastewater would be neutralized and loss of the acid by either oxidation of the organic acids or reduction and assimilation of the inorganic acid would raise the $\mathrm{pH}$ due to excess cation but not perhaps in the absence of bacterial growth. Although strain DK6 will utilize many organic acids (Table 2) their metabolism with these microaerobic conditions would result in an excess of cation this would be partially compensated by $\mathrm{CO}_{2}$ production that could not escape because the tubes were closed tightly with Teflon screw caps. Another possibility for an increase in $\mathrm{pH}$ is the conversion of the organic- $\mathrm{N}$ into ammonium ion (ammonification). However because the increase of $\mathrm{pH}$ occurred in the absence of bacterial growth the increase is more likely due to some non biological process such as photooxidation. Whatever the cause one advantage of an increase in $\mathrm{pH}$ could be the precipitation of phosphate, (Bitton, 1994; Cohen and Kirchmann, 2004), thereby preventing eutrophication of surface waters. Although phosphate removal was not investigated in the present study rubber sheet wastewater does contain phosphate $448 \mathrm{mg} / \mathrm{L}$ (Kantachote and Innuwat, 2004).

The growing bacteria produced a significant reduction of BOD and COD (Figure 6a and Figure 6c). The small loss of BOD (6\%) with no COD reduction in SOW indicates that abiotic degradation occurred and this was possibly due to photooxidation of some non-organic material able to contribute to the BOD. This also caused some increase in turbidity and $\mathrm{pH}$ (Figure 6). The absence of COD reduction in SOW indicates that no mineralization of organic matter occurred by photooxidation as COD is the amount of oxygen necessary to oxidize organic matters to $\mathrm{CO}_{2}, \mathrm{H}_{2} \mathrm{O}$ and $\mathrm{NH}_{3}$ (Bitton, 1994). In the case of ROW there was a higher reduction of BOD (70\%) than of COD (54\%). This may not be significant because, if we assume that the reduction in COD of $3957 \mathrm{mg} / \mathrm{L}$ was due mainly to the loss of readily utilizable compounds that contributed to the initial BOD of $4967 \mathrm{mg} / \mathrm{L}$ their removal would have reduced the final BOD to $1010 \mathrm{mg} / \mathrm{L}$ a loss of about $80 \%$. 
We can therefore assume that some of the compounds lost in the COD estimations did not contribute to the initial BOD. In the presence of isolate DK6 in either pure culture and as a mixed culture with indigenous microbes a $90 \%$ reduction of both BOD and COD was obtained. The lower reduction of COD in ROW compared to that of both SOW + DK6 and ROW + DK6 indicates that isolate DK6 was able to metabolise most of the organic matter in the wastewater while the indigenous microbes were not. In this sense strain DK6 would be a most useful addition to any process treating rubber wastewater. Other workers have used PNSB for treating rubber wastewaters in laboratory tests, for example mixed cultures of Rubrivivax gelatinosus SS51 and SY40 were used with an optimum ratio of 14:7 ( $\mathrm{ml} / \mathrm{ml}$ : as approximately cell dry wt. of $0.25 \mathrm{mg} / \mathrm{ml}$ ) and they reduced the COD of the concentrated latex wastewater by only $57 \%$ (Choorit et al. 2002).

The protein content of PNSB strain DK6 (65.2\%) was similar to that of Rhodocyclus gelatinosus R1 (67.7\%) grown with poultry slaughterhouse wastewater under anaerobic light conditions (Ponsano et al. 2003). Isolate DK6 has therefore a great potential for use as SCP (Sasaki et al. 1991; Sasikala and Ramana, 1995). However, the process productivity of the isolate DK6 was low (0.10 $\mathrm{g} / \mathrm{L}$.day) but much better (2.4 g/L.day) in the presence of indigenous microbes. Photosynthetic bacteria typically have lower process productivity than heterotrophic bacteria because the cell densities achieved are low (Kobayashi and Kurata, 1978). This is in agreement with Ponsano et al. 2003 where the process productivity of Rhodocyclus gelatinosus R1 was around $0.072 \mathrm{~g} / \mathrm{L}$.day. With regard to cell yields with normal heterotrophs growing with aerobic growth conditions $50 \%$ of organic carbon can be converted to biomass, whereas with anaerobic conditions only $5 \%$ is converted into biomass (Speece, 1983).

In conclusion PNSB strain DK6 when added to a system treating wastewater from rubber sheet processes has the potential to improve the treatment process without any considerable increase in costs and may also be harvested and after further tests for absence of toxicity find use as SCP. Further work on scale up of the process is continuing for adaptation to field conditions.

\section{ACKNOWLEDGEMENTS}

Authors would like to thank Dr. Brian Hodgson for his critical reading of the manuscript.

\section{REFERENCES}

AOAC (Association of Official Analytical Chemists). Official method of analysis.17th ed. vol. 2 part B, Arlington, Virginia, 2002. 2200 p. ISBN 0-935584-67-6.

APHA, AWWA and WPCF. Standard method for the examination of water and wastewater. 20th ed. Washington, D.C., American Public Health Association,
1998. 1325 p. ISBN 0-87553-235-7.

ATLAS, R.M. and BARTHA, R. Microbial ecology: fundamentals and applications. 4th ed. Menlo Park, California; Benjamin/Cummings Science Publishing, 1998. 694 p. ISBN 0-8053-0655-2.

BITTON, G. Wastewater microbiology. New York; WileyLiss, 1994. 478 p. ISBN 0-471-30985-0.

COHEN, Y. and KIRCHMANN, H. Increasing the $\mathrm{pH}$ of wastewater to high levels with different gases-CO2 stripping. Water, Air, and Soil Pollution, November 2004, vol. 159, no. 1, p. 265-275.

CHOORIT, W.; THANAHOSET, P.; THONGPRADISTHA, J.; SASAKI, K. and NOPARATNARAPORN, N. Identification and cultivation of photosynthetic bacteria in wastewater from a concentrated latex processing factory. Biotechnology Letters, July 2002, vol. 24, no. 13, p. 1055-1058.

HOLT, J.G.; KRIEG, N.R.; SNEATH, P.H.A.; STALEY, J.T. and WILLIAMS, S.T. Bergey's manual of determinative bacteriology. 9th. Baltimore; The Williams and Wilkins Co., 1994. 787 p. ISBN 0-683-00603-7.

HOOGEWERF, G.J.; JUNG, D.O. and MADIGAN T. Evidence for limited species diversity of bacteriochlorophyll b-containing purple nonsulfur anoxygenic phototrophs in freshwater habitats. FEMS Microbiology Letters, January 2003, vol. 218, no. 2, p. 359364.

HU, X.; LAM, F.L.Y.; CHEUNG, L.M.; CHAN, K.F.; ZHAO, X.S. and LU, G.Q. Copper/MCM-41 as catalyst for photochemically enhanced oxidation of phenol by hydrogen peroxide. Catalysis Today, 2001, vol. 68, no. 1-3, p. 129133.

IMHOFF, J.F. and TRÜPER, H.G. Purple nonsulfer bacteria. In: STALEY, J.T. ed. Bergey's Manual of Systematic Bacteriology. Baltimore, Williams \& Wilkins, 1989, vol. 3, p. 1658-1682.

IZU, K.; NAKAJIMA, F.; YAMAMOTO, K. and KURISU, F. Aeration conditions affecting growth of purple nonsulfur bacteria in an organic wastewater treatment process. Systematic and Applied Microbiology, 2001, vol. 24, no. 2, p. 294-302.

KANTACHOTE, D. and INNUWAT, W. Isolation of Thiobacillus sp. for use in treatment of rubber sheet wastewater. Songklanakarin Journal of Science and Technology, September-October 2004, vol. 26, no. 5, p. 649-657.

KIM, M.K.; CHOI, K.M.; YIN, C.R.; LEE, K.Y.; IM, W.T.; LIM, J.H. and LEE, S. Odorous swine wastewater 
treatment by purple non-sulfur bacteria, Rhodopseudomonas palustris, isolated from eutrophicated ponds. Biotechnology Letters, May 2004, vol. 26, no. 10, p. 819-822.

KOBAYASHI, M. and KURATA, S. The mass culture and cell utilization of photosynthetic bacteria. Process Biochemistry, 1978, vol. 13, no. 9, p. 27-30.

KOH, L.H.; KUHN, D.C.S.; MOHSENI, M. and ALLEN, D.G. Utilizing ultraviolet photooxidation as a pre-treatment of volatile organic compounds upstream of a biological gas cleaning operation. Journal of Chemical Technology and Biotechnology, April 2004, vol. 79, no. 6, p. 619-625.

ORMEROD, J.G.; ORMEROD, K.S. and GEST, H. Lightdependent utilization of organic compounds and photoproduction of molecular hydrogen by photosynthetic bacteria; relationships with nitrogen metabolism. Archives of Biochemistry and Biophysics, 1961, vol. 94, p. 449.

PFENNIG, N.Rhodopseudomonas acidophila, sp. n., a new species of the budding purple nonsulfur bacteria. Journal of Bacteriology, 1969, vol. 99, no. 2, p. 597-602.

PONSANO, E.H.G.; LACAVA, P.M. and PINTO, M.F. Isolation of Rhodocyclus gelatinosus from poultry slaughterhouse wastewater. Brazilian Archives of Biology and Technology, July 2002, vol. 45, no. 4, p. 1-8.

PONSANO, E.H.G.; LACAVA, P.M. and PINTO, M.F. Chemical composition of Rhodocyclus gelatinosus biomass produced in poultry slaughterhouse wastewater. Brazilian Archives of Biology and Technology, March 2003, vol. 46, no. 2, p. 1-11.

PRASERTSAN, P.; JATURAPORNPIPAT, $M$. and SIRIPATANA, C. Utilization and treatment of tuna condensate by photosynthetic bacteria. Pure and Applied Chemistry, 1997, vol. 69, no. 11, p. 2439-2445.

SASAKI, K.; NOPARATNARAPORN, N. and NAGAI, S. Use of photosynthetic bacteria for the production of SCP and chemicals from agroindustrial wastes. In: Martin, A.M. ed. Bioconversion of waste materials to industrial product, 4. New York, New York Universities Press, 1991, p. 225226.

SASIKALA, G.H. and RAMANA, C.H.V. Biotechnological potentials of anoxygenic phototrophic bacteria. I. production of Single-Cell Protein, vitamins, ubiquinones, hormones, and enzymes and use in waste treatment. Advances in Applied Microbiology, 1995, vol. 41, p. 173-226.

SAWAYAMA, S.; HANADA, S. and KAMAGATA, Y. Isolation and characterization of phototrophic bacteria growing in lighted upflow anaerobic sludge blanket reactor.
Journal of Bioscience and Bioengineering, 2000, vol. 89, no. 4, p. 396-399.

SPEECE, R.E. Anaerobic biotechnology for industrial waste treatment. Environmental Science Technology, 1983, vol. 17, no. 9, p. 416A-427A.

TADESSE, I.; ISOAHO, S.A.; GREEN, F.B. and PUHAKKA, J.A. Removal of organics and nutrients from tannery effluent by advanced integrated wastewater pond systems technology. Water Science and Technology, 2003, vol. 48, no. 2, p. 307-314.

TALU, G.F. and DIYAMANDOGLU, V. Formate ion decomposition in water under UV irradiation at $253.7 \mathrm{~nm}$. Environmental Science and Technology, July 2004, vol. 38 no.14, p. 3984-3993.

VEENSTRA, S.; Al-NOZAILY, F.A. and. ALAERTS, G.J. Purple non-sulfur bacteria and their influence on waste stabilization pond performance in the Yemen Republic. Water Science and Technology, 1995, vol. 31, no. 12, p. 141-149.

ZHU, H.; UEDA, S.; ASADA, Y. and MIYAKE, J. Hydrogen production as a novel process of wastewater treatment-studies on tofu wastewater with entrapped R. sphaeroides and mutagenesis. International Journal of Hydrogen Energy, 2002, vol. 27, no. 11-12, p. 1349-1357. 